ISSN: 0213-2079 - ISSN electrónico: 2386-3889

DOI: http://dx.doi.org/10.14201/shhmo201537183210

\title{
LAS OBRAS PÍAS COMO CAMINO DE SALVACIÓN: EL OBISPADO DE ALBARRACÍN (SIGLO XVII) ${ }^{1}$
}

\section{Pious works as a Path to Salvation: the Bishopric of Albarracin (XVII century)}

José Manuel LATORRE CIRIA

Universidad de Zaragoza

Correo-e: jlatorre@unizar.es

RESUMEN: El trabajo pretende mostrar el papel de las obras pías como instrumento de salvación, como expresión de unas formas de religiosidad que tuvieron también hondas repercusiones sociales. Se estudia el caso del obispado de Albarracín durante el siglo Xvir. El estudio se sustenta principalmente sobre la información suministrada por las visitas pastorales, el libro de instituciones de capellanías y sendos informes sobre el obispado redactados a comienzos y a finales del xvir. La fundación de capellanías y beneficios responde a la búsqueda de gracias espirituales, pero estos instrumentos ofertados por la Iglesia a los fieles como camino de salvación ofrecían evidentes ventajas sociales. A través de estos instrumentos se podía asegurar el futuro de un pariente, se perpetuaba la memoria y el nombre del fundador y la vanidad de los linajes quedaba satisfecha. Las obras pías eran instrumentos de salvación, pero también de solidaridad y apoyo a la familia.

Palabras clave: Iglesia; religiosidad; beneficio; capellanía; limosna.

ABSTRACT: This article intends to show the role that various pious works play as instruments of salvation and as an expression of certain

1. Este trabajo se inscribe en el proyecto de $\mathrm{I}+\mathrm{D}$ del Ministerio de Economía y Competitividad HAR2011-28732-C03-03 y en los trabajos del grupo de investigación «Blancas» (Gobierno de Aragón). 
forms of religiousness that had deep social repercussions. We highlight the case of the bishopric of Albarracín during the xvir century. The study is mainly concerned with the information furnished by pastoral visits, the book of chaplaincy institutions and two reports on the bishopric written toward the start and the end of the XVII century respectively. The founding of chaplaincies and benefices was effected as an answer to the search for spiritual graces; however these institutions which were offered to the faithful by the Church as paths to salvation provided clear social advantages. Through these institutions the future of a family member could be secured. The memory and name of the founder perpetuated and the vanity of the linages was satisfied. Pious works were instruments of salvation, but also of solidarity, and family support.

Key words: Church; Religiousness; Benefice; Chaplaincy; Alms.

La llegada de la hora de la muerte y, por tanto, del momento de rendir cuentas ante Dios, preocupó hondamente a los hombres del pasado. Tras el óbito se abría la eternidad, la cual podía vivirse de muy diferente forma, según el destino del alma fuera el cielo, el infierno o el purgatorio, los tres lugares del más allá. Desde la Baja Edad Media la predicación de la Iglesia insistió en la importancia del momento de la muerte para la salvación; era fundamental el arrepentimiento y la ayuda de los sacramentos en ese trance final, así como unas adecuadas disposiciones testamentarias que dedicasen una parte del caudal acumulado en favor de la propia alma. Esta podía perderse o, por el contrario, salvarse en los instantes finales de la agonía.

El pensamiento sobre la muerte y el purgatorio adquiere un protagonismo esencial. La idea del purgatorio como lugar intermedio entre el cielo y el infierno, lugar de purgación, de purificación para las almas en tránsito hacia el cielo, alimentó todo un sistema de intercesión de los vivos por los muertos, de solidaridad entre los allegados, destinado a tranquilizar las conciencias, cuyo intermediario natural fue el clero².

La catequización postridentina contribuirá a afianzar este esquema a la vez que desarrollará una religiosidad que se expresa, sobre todo, a través de las ceremonias de culto protagonizadas por el clero, donde el creyente participa, en buena medida, como espectador. Predominan las manifestaciones exteriores de la religiosidad desarrolladas comunitariamente, como un acto colectivo de adoración a Dios, más que de vivencia de Dios.

2. Le Goff, J.: El nacimiento del Purgatorio. Madrid, 1985, p. 156. 
El concilio de Trento recordó que el purgatorio existía y que las almas detenidas en él recibían alivio con los sufragios de los fieles, y en especial con el sacrificio de la misa. Los obispos habían de ocuparse de que los sufragios de los fieles - misas, oraciones, limosnas y otras obras de piedad-se ejecutasen según lo establecido por la Iglesia ${ }^{3}$. El valor salvador de las obras se reforzó tras la puesta en cuestión de las mismas por parte de los reformadores protestantes. No debía quedar duda alguna sobre el valor de las buenas obras en el camino hacia la salvación.

El purgatorio aparece, a los ojos de los tratadistas barrocos, como un lugar real donde las almas se purifican por las culpas no redimidas en la vida terrenal. Se describe el purgatorio como un lugar de sufrimiento, con castigos similares a los del infierno, donde no reina la alegría por la cercanía del paraíso. Se sabe que no se permanece allí para toda la eternidad, pero la incertidumbre sobre la duración del tránsito es total. No hay acuerdo entre los teólogos sobre la duración de la presencia en el purgatorio, pero se tiende a pensar que la estancia allí puede ser muy larga. En todo caso, solo Dios lo sabe. El purgatorio, así concebido, sin duda suscita miedo y por ello es necesario ir bien pertrechados de buenas obras para acortar en lo posible la estancia en ese sombrío lugar. Los sufragios obtenidos con las fundaciones de misas, de obras de caridad o de otras buenas acciones eran fundamentales. Como también lo era la solidaridad de los vivos para con los muertos, manifestada en las continuas oraciones en favor de las almas del purgatorio. Los santos, por su parte, invocados por los creyentes, eran importantes aliados en la tarea de liberar a las almas de la estancia en el lugar de purgación ${ }^{4}$.

Esta visión religiosa del problema de la salvación alimentó las fundaciones piadosas destinadas a la salvación de las almas. El código de derecho canónico entiende por fundaciones pías los bienes temporales entregados a alguna persona moral eclesiástica, con la carga perpetua o por largo tiempo de, con las rentas anuales de los capitales o bienes donados, decir algunas misas, o celebrar otras funciones eclesiásticas señaladas, o practicar determinadas obras piadosas o de caridad. La reducción de las cargas que gravan a las fundaciones piadosas corresponde a la Santa Sede y, en caso de reducirse, lo último en sufrir merma serán las misas 5 .

3. Concilio de Trento, Sesión XXV, celebrada en diciembre de 1563.

4. García Hinojosa, P.: Simbolismo, religiosidad y ritual barroco. La muerte en el siglo XVII. Zaragoza, 2013, pp. 66-87. López-Guadalupe Muñoz, J. J.: «Imágenes del más allá. Culto e iconografía de las ánimas en la Granada moderna», en Cortés PEÑA, A. L. (ed.): Poder civil, Iglesia y sociedad en la Edad Moderna. Granada, 2006, pp. 161-164. Prosperi, A.: El concilio de Trento. Una introducción histórica. Ávila, 2008, pp. 133-135.

5. Código de derecho canónico. Código de 1917. Versión castellana anotada por L. Miguélez, S. Alonso y M. Cabreros, Madrid, BAC, 1978, título XXX, 1.544-1.551. En términos generales, un legado pío es «una porción de rentas o bienes asignados por el testador para una obra de piedad o beneficencia...; así, por un legado pío se pueden dejar bienes para un beneficio, para una capellanía, 
Las fundaciones fueron el medio habitual que tuvieron los fieles de ocuparse de sus almas, aportando fondos para dotar limosnas, beneficios, capellanías o simples misas por el alma. El gesto de generosidad que supone la fundación aporta beneficios espirituales, pero también sociales, en tanto en cuanto las cláusulas de las fundaciones suelen acordarse de los familiares, bien sea como destinatarios de la limosna o como encargados, en caso de ser eclesiásticos, de oficiar las misas vinculadas a los beneficios o capellanías. También es oportuno resaltar que cumplían con la función de perpetuar la memoria del donante, cuyo nombre quedaba asociado a determinadas capillas de las iglesias donde se fundaban los beneficios o capellanías, quedando así perenne noticia del linaje familiar. Se amalgaman, por tanto, distintas finalidades en las fundaciones pías: salud del alma en el más allá, apoyo a los familiares y perpetuación de la memoria del individuo donante y de su familia.

A lo largo de este trabajo se pretende mostrar las obras pías fundadas por los fieles en el obispado de Albarracín durante el siglo xviI, esto es, los beneficios simples, las capellanías, las limosnas y las celebraciones o memorias de misas, atendiendo fundamentalmente a su papel como instrumentos de salvación, como expresión de unas formas de religiosidad que tuvieron también hondas repercusiones sociales. Albarracín es la cabeza de una diócesis pequeña, ubicada en una zona montañosa del sur aragonés, segregada del obispado de Segorbe en el último tercio del siglo Xvi como consecuencia de la reorganización eclesiástica impulsada por Felipe II. El estudio se sustenta principalmente sobre la información suministrada por las visitas pastorales, el libro de instituciones de capellanías y sendos informes sobre el obispado redactados a comienzos y a finales del XviI ${ }^{6}$.

\section{Las obras PÍAS EN El SÍNOdo De Albarracín DE I604}

El sínodo de 1604, celebrado en Albarracín 7 , dedica, como era habitual en las asambleas sinodales de la época, diversas disposiciones relativas a las obras pías con el fin de garantizar su cumplimiento y buena administración de los bienes a

para una fundación pía y para otros muchos fines religiosos»; González RuIz, M.: «Las capellanías españolas en su perspectiva histórica», Revista Española de Derecho Canónico, 14, 1950, pp. 482-485.

6. Archivo Diocesano de Albarracín [en adelante ADA], Visitas pastorales de 1587 y 1591; S. Utienes, Relación del estado de la catedral y diócesis de Albarracín, 1619; Relación sumaria II, 16651670; Libro de la institución de capellanías del obispado de Albarracín hasta el año 1788. PoLo, J. J.: «La visita pastoral del obispo Pedro Jaime a la diócesis de Albarracín (1598-1599)», Teruel, 77-78, 1987, pp. 237-260.

7. Synodo Diocesana, celebrada en la Ciudad de Santa María de Albarrazín, en el mes de Mayo, de 1604 / presidiendo en ella el muy Illustre ... Fray Don Andres Balaguer Obispo ... Barcelona, Sebastián de Cormellas, 1604. 
ellas vinculados. No contiene, por tanto, un corpus doctrinal sobre la materia, sino que se ocupa de los aspectos relacionados con su administración.

Cada parroquia debía de disponer de un libro donde se anotasen el día, mes y año de la muerte de cada uno de los feligreses, las obras pías que hubieren dejado en sus testamentos y el notario que las testificó; se dejaría constancia, asimismo, de los fallecidos sin testamento y de las obras pías que hubiesen ordenado. Un libro similar, pero general para todo el obispado, debía confeccionarse en la sede del obispo con la información remitida por los párrocos.

Con el paso del tiempo, existía el riesgo de que los legados y sus inversiones se perdieran si el control no era minucioso. Por eso, el sínodo dispone la obligación de antipocar, es decir, de acudir al notario periódicamente - cada cinco años-, para reconocer de nuevo la obligación de pagar un censo o renta a las obras pías. Todos los derechos, rentas y propiedades pertenecientes a estas obras se debían registrar en un libro, junto a una descripción y ubicación de las mismas, y una indicación expresa del notario que testificó los actos.

Las ventas de inmuebles o tierras sobre las que pesaba alguna carga -censal o treudo- en beneficio de alguna obra pía, era una ocasión propicia para la pérdida de la renta; por ello, queda establecido que no podían efectuarse sin dejar constancia, en la escritura de compraventa, de la imposición que pesaba sobre la propiedad, por tanto de la obligación de pago del comprador, y de la persona que donó la renta.

La enajenación de los bienes vinculados a fines piadosos quedaba sujeta a la acreditación, mediante testigos, de su necesidad, además de dar publicidad a la venta mediante edictos para dar opción a manifestar, por quien así lo considerase oportuno, razones en contra de tal acto. Solo tras dar cumplimiento a este procedimiento, el ordinario podía autorizar la transacción. La misma autorización de la autoridad diocesana es necesaria para asegurar censales sobre propiedades pertenecientes a las obras pías.

Se presta una notable atención a los testamentos, solicitando de los párrocos que exhorten a los fieles para que los realicen cuando están bien de salud, sin esperar al último momento, y a que en ellos expresen y declaren las misas, aniversarios y otras obras pías que quieren se hagan por sus almas, sin dejarlas a la voluntad de los herederos o ejecutores testamentarios. En el sínodo de 1690 se añade, como obligación de los sacerdotes, que al visitar a los enfermos les adviertan que en sus disposiciones testamentarias no pueden llamar a sacerdotes de otras parroquias para sus funerales, pues los clérigos locales deben ser preferidos a los de fuera ${ }^{8}$.

8. Sinodo Diocesana que se celebró en la ciudad de Albarracín a 9 de abril del año 1690: presidiendo en ella su obispo el muy ilustre, y reverendísimo señor Don Fr. Miguel Geronimo Fuenbuena. Zaragoza, Pasqual Bueno, 1690, título 3. ${ }^{\circ}, 2$. 
Hay personas que no hacen testamento, pero manifiestan su propósito de dotar obras pías. Si existen testigos que lo acrediten, los herederos están obligados a respetar sus intenciones. Por su parte, los párrocos, quedan autorizados para exigir su cumplimiento a los ejecutores testamentarios.

La normativa sinodal apuesta claramente por fomentar el testamento y por ello se ordena que nadie estorbe al enfermo cuando pide un notario para testar. Manda, asimismo, a los clérigos que no hagan violencia a los enfermos para que dispongan mandas a favor de sus iglesias, o dejen otros legados de los cuales ellos o sus parientes puedan sacar provecho.

Si el testador no precisa legados píos y remite a sus ejecutores testamentarios o herederos el encargo de los mismos, estos quedan obligados a cumplir con ellos según la condición económica y social del difunto, tras el obligado consentimiento de los párrocos. Si esta obligación no queda satisfecha, el obispo podrá disponer un testamento sobre el cuerpo del difunto, como si hubiera fallecido sin expresar sus últimas voluntades, y ordenar así las misas y obras pías que le corresponderían de acuerdo a su estatus. Esta prerrogativa de la autoridad eclesiástica se basaba en la creencia de que nadie debía abandonar la tierra sin los correspondientes sufragios por su alma; por tanto, testar sobre el cuerpo para ordenar los gastos en el entierro, las misas y otros oficios litúrgicos era un deber de caridad, aunque el efecto colateral era, también, garantizar unos ingresos al clero parroquial ${ }^{9}$.

En definitiva, el sínodo regula minuciosamente todo el procedimiento de gestión burocrática de los legados con la finalidad de que no se pierdan y garantizar así el cumplimiento de la voluntad de los testadores y el adecuado ingreso para los clérigos.

La labor de vigilancia del cumplimiento de estas disposiciones corresponde al obispo o sus visitadores, que se ocupan de comprobar si las misas fundadas se ofician, si se cumplen las disposiciones testamentarias o si las capillas de las capellanías están con el adecuado decoro. También se observa un control sobre la acumulación de capellanías por un mismo clérigo ${ }^{10}$.

9. García Hinojosa, op. cit., pp. 247-252.

10. En la visita pastoral de 1645 a Orihuela del Tremedal se ordena a mosén Pedro Martínez, habitante en Noguera, poseedor de tres capellanías fundadas respectivamente en Orihuela, Noguera y Monterde, que elija una de las tres y abandone las otras dos, pues todas son de residencia obligatoria. Por otra parte, al capellán de la capellanía de los Cañetes, que no celebra las misas, se le manda que las celebre o, de lo contrario, no se le pague y se mande celebrar a otro clérigo: Archivo Parroquial de Orihuela [en adelante APO], libro de difuntos, 12-01-1645. 


\section{LAS LIMOSNAS}

Las limosnas dispuestas en las últimas voluntades fueron una de las formas de practicar las buenas obras con el fin de lograr la salvación, pues se tiene claro que la caridad es del agrado de Dios, como bien lo expresa mosén Juan García en su institución de limosna ${ }^{11}$. Las personas suelen dejar algunas sumas para dotar limosnas en todas las parroquias del obispado, aunque, obviamente, es en las localidades con un mayor número de habitantes donde se instituyen más fundaciones; de hecho, en los seis primeros pueblos por población encontramos, al menos, diez limosnas. El total de limosnas registradas entre finales del siglo xvi y la segunda década del Xvir es de 160 (Cuadro 1) y la media por localidad asciende a casi siete. Fueron fundadas en los siglos Xvi y Xvir, aunque cabe hacer la salvedad de que solo se conoce el momento de fundación en $85 \operatorname{casos}^{12}$.

Las limosnas tienen como objetivos fundamentales atender a los pobres $(38,75 \%)$ y a las jóvenes sin recursos en la hora de su matrimonio, aportando alguna suma para que pudieran disponer de dote (39,38\%); estas dos finalidades aparecen en el 78 por ciento de las limosnas del obispado. Un poco más de un diez por ciento se destinan a becar estudiantes, mientras algo más del once por ciento se reparte entre finalidades diversas, como donativos a hospitales, compra de velas para alumbrar en las iglesias, ayuda para pagar al maestro del pueblo ${ }^{13}$, trigo para prestar a los labradores pobres o la compra de alguna bula de difuntos.

Las limosnas para casar doncellas contemplan, en algunos casos, que se otorguen a doncellas honestas y virtuosas, que se casen con voluntad de los padres y que no sean manifestadas ni secuestradas. Sin embargo, también se dan fundaciones, como las llevadas a cabo por el obispo Jerónimo Salas Malo o el canónigo Terzán, donde se abre la posibilidad de que accedan a su disfrute igualmente muchachas que hayan cometido algún pecado de deshonestidad o que hubieran vivido o viviesen deshonestamente ${ }^{14}$.

11. «ya muchos días y tiempo que tengo y haya tenido muy grande deseo por salvar mi alma de instituir y fundar una limosna de mis bienes y hacienda para fin de casar doncellas pobres y huérfanas de mi genealogía y tronco por entender cuan accepta es a Dios la caridad bien ordenada»: ADA, Libro de la institución de capellanías del obispado de Albarracín hasta el año 1788, fol. 83.

12. En los valles del Jalón y Jiloca la mitad de los legados píos se fundan a partir de 1570: Catalán Martínez, E.: «Seculares aragoneses después de Trento. La visita pastoral de D. Antonio Chacón a los valles del Jalón y Jiloca», Jerónimo Zurita, 76-77, 2004, p. 393.

13. Beatriz Soriano, de Jabaloyas, fundó, en 1595, una limosna dotada con 100 sueldos de renta anual para ayudar a pagar a un maestro que enseñase a los niños y estudiantes: ADA, S. Utienes, Relación del estado de la catedral y diócesis de Albarracín, 1619, fol. 166.

14. ADA, Libro de la institución de capellanías del obispado de Albarracín hasta el año 1788, fol. 83, fol. 709 y ss., fol. 720; S. Utienes, Relación del estado de la catedral y diócesis de Albarracín, 1619, fols. 32v-35v y 61v.; Relación sumaria II, 1655-1670, fol. 121. 
El colectivo social más numeroso entre los fundadores de limosnas es el clero ${ }^{15}$, cuyos miembros fundaron 62 limosnas, es decir el 38,75 por ciento del total (Cuadro 2). Los clérigos se acordaron, sobre todo $-45,16 \%$ de los casos- de dotar doncellas, asistir a los pobres $(32,26 \%)$ o becar estudiantes (12,90\%); también hay algunos que donan trigo para prestarlo sin intereses a los labradores necesitados, con la obligación de devolverlo tras recoger la cosecha, en el mes de agosto.

Las limosnas, además de servir para el bien del alma del donante, cumplen, con frecuencia, otra finalidad, como es socorrer a los parientes necesitados de los testadores. Las limosnas amalgaman así dos elementos importantes para las personas de la época: socorrer a la propia alma a la vez que se apoya a los miembros de la misma estirpe, es decir, hay un compromiso con los mandatos de la religión pero, al mismo tiempo, se encuentra el modo de atender económicamente a los descendientes de la propia sangre. Las donaciones destinadas a personas vinculadas al linaje de los donantes suponen el 46,26 por ciento de los casos, concentrados en las finalidades de casar doncellas, atender a los pobres y becar a estudiantes. Este porcentaje sube hasta el 51,61 por ciento en el caso de los clérigos, que muestran un decidido apoyo a sus familias, una valoración del vínculo familiar en el momento de la disposición de sus bienes a la hora de la muerte. Por otra parte, es muy frecuente que los donantes establezcan que, en ausencia de familiares, la limosna se entregue a personas de la localidad donde se funda ${ }^{16}$.

La cuantía de las limosnas ofrece una amplia dispersión. Se pueden encontrar desde 4.000 sueldos hasta tan solo de uno o dos. El promedio de las rentas donadas para las limosnas asciende a 415 sueldos, una cantidad moderada. Nuevamente se observa una diferencia entre el conjunto y el comportamiento de los clérigos, los cuales fundaron limosnas cuyo importe medio asciende a 553 sueldos. Sin duda su mayor capacidad económica, por regla general, y el hecho de no tener descendencia directa les permitió ser más generosos en este tipo de donaciones, amén de la influencia de una fe, en principio, más firme por su condición de líderes espirituales. Las rentas asignadas a estas limosnas proceden, generalmente, de censales, aunque en algunos casos se vinculan tierras o casas.

15. También en otras partes de Aragón: Catalán Martínez, op. cit., p. 393. Los canónigos de la catedral de Pamplona igualmente se ocuparon de fundar limosnas y capellanías: Ardanaz, N.: La catedral de Pamplona en el siglo de las luces. Arte, ceremonial y cultura. Pamplona, 2011, pp. 196, 315 y ss.

16. Sobre los legados píos para casar doncellas y otras finalidades en el País Vasco, vid. Catalán Martínez, E.: El precio del Purgatorio. Los ingresos del clero vasco en la Edad Moderna. Bilbao, 2000, pp. 173-176. 


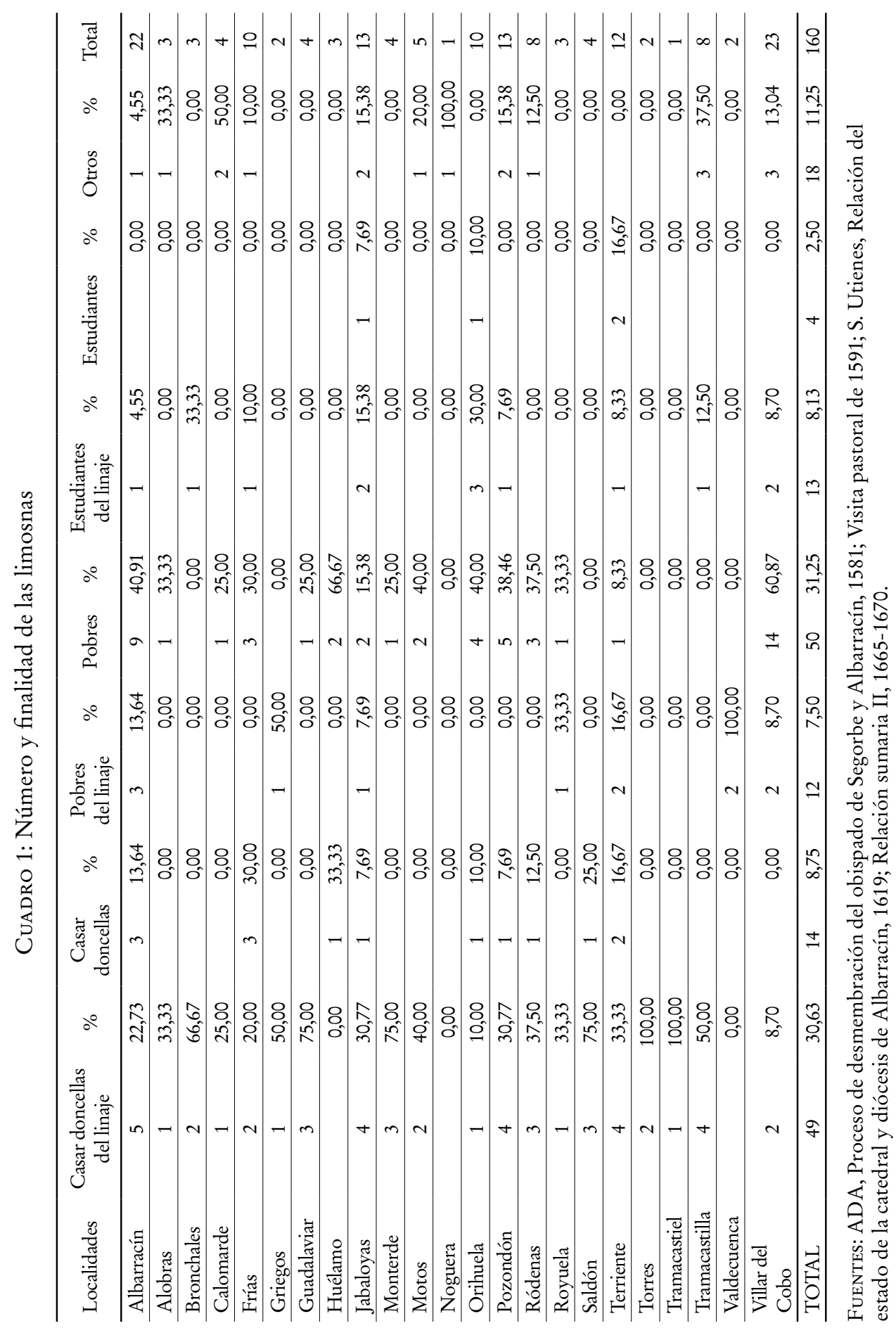




\begin{tabular}{|c|c|c|c|c|c|c|c|c|c|c|c|c|c|c|c|c|c|c|c|}
\hline 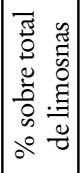 & 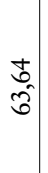 & $\begin{array}{l}8 \\
8 \\
8\end{array}$ & $\begin{array}{l}8 \\
8 \\
0 \\
i n\end{array}$ & $\begin{array}{l}8 \\
8 \\
\text { in }\end{array}$ & & $\begin{array}{l}8 \\
\text { ปึ }\end{array}$ & $\begin{array}{l}\frac{1}{2} \\
\text { fó }\end{array}$ & $\begin{array}{l}8 \\
\text { బิ } \\
\text { an }\end{array}$ & $\begin{array}{l}8 \\
8 \\
8\end{array}$ & Q & $\begin{array}{l}f \\
\text { to } \\
m \\
m\end{array}$ & 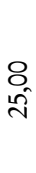 & $\stackrel{\hat{m}}{\hat{m}}$ & $\begin{array}{l}8 \\
8 \\
i n\end{array}$ & & $\begin{array}{l}8 \\
8 \\
8\end{array}$ & 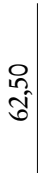 & $\begin{array}{c}\hat{2} \\
\hat{=}\end{array}$ & \\
\hline 胥 & \pm & $m$ & $v$ & $v$ & 0 & - & 0 & -1 & in & $\wedge$ & in & $N$ & - & $N$ & - & -1 & in & + & $\widehat{\sigma}$ \\
\hline
\end{tabular}

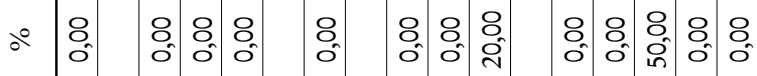

$\stackrel{\infty}{0}$

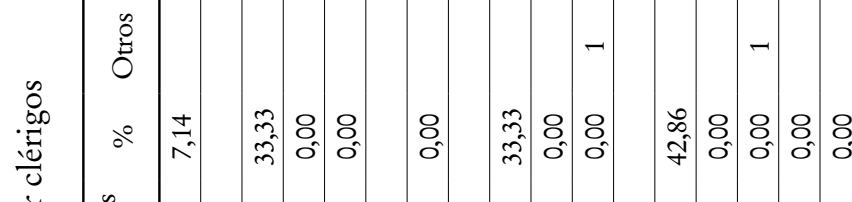

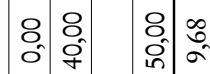

总:

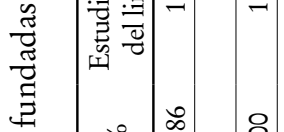

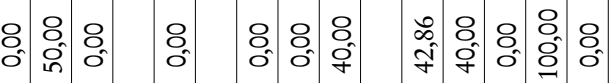

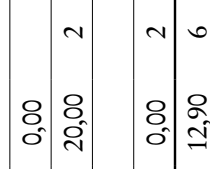

官

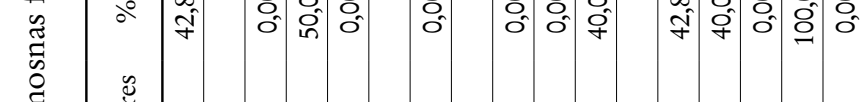

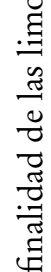

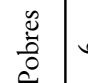

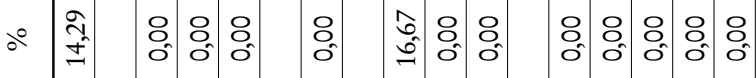

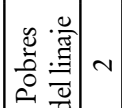

A

००

商

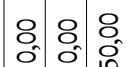

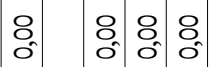

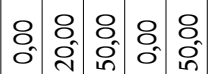

8.

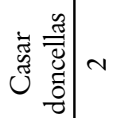

r

岁

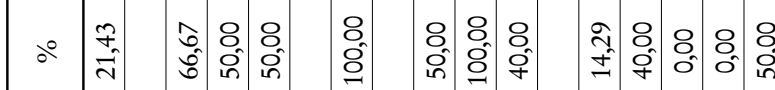

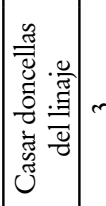

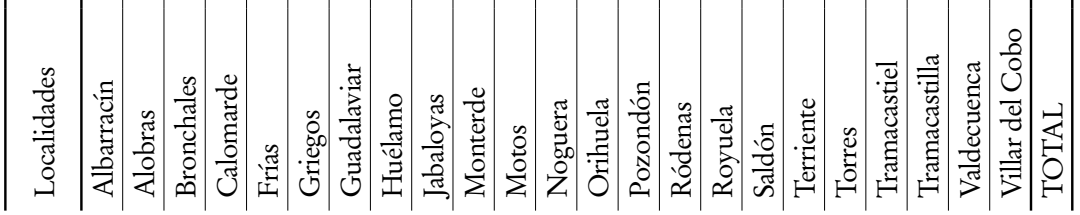

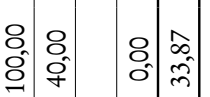

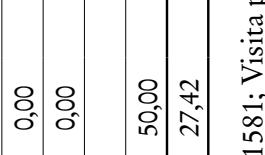

o.

咅

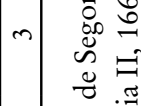

$\ddot{\bar{\sigma}}$ 


\section{LOS BENEFICIOS}

El beneficio eclesiástico es una entidad jurídica constituida a perpetuidad por la competente autoridad eclesiástica, que consta de un oficio sagrado y del derecho a percibir las rentas anejas por la dote al oficio ${ }^{17}$. La dote del beneficio la pueden integrar los bienes cuya propiedad le pertenecen, las prestaciones debidas de alguna familia o persona moral, las ofrendas ciertas y voluntarias de los fieles, los derechos de estola o las distribuciones corales. Además del oficio beneficial pueden llevar aneja, o no, la obligación de residir y la cura de almas y pueden ser perpetuos o revocables. Para constituir un beneficio se precisa dote congrua y estable, cuyos réditos se perciban a perpetuidad ${ }^{18}$.

Los beneficios de los que aquí me voy a ocupar se refieren a los fundados por particulares con la finalidad primera de realizar una buena obra para su salvación y la de sus familiares; son los llamados beneficios simples, sin cura de almas a su cargo. Los fundadores conservan el derecho de patronato, que suelen transmitir a sus herederos, entendido por el derecho canónico como el conjunto de privilegios, con ciertas cargas, que por concesión de la Iglesia competen a los fundadores católicos de una iglesia, capilla o beneficio. El patrón conserva el derecho de presentar al clérigo para el beneficio vacante, aunque pertenece al ordinario juzgar si la persona presentada es idónea y otorgarle, en consecuencia, la oportuna colación canónica.

La diócesis de Albarracín cuenta con 22 beneficios fundados por particulares, todos ellos concentrados en la capital del obispado y la mayoría ubicados en la catedral. Solamente, en la visita pastoral de 1587, se menciona la existencia de uno en la parroquia de Santiago y, en 1619, se cita otro en la iglesia de Santa María, el llamado del Alba y de Palomarejos, fundado en 1364 por García Sánchez de Arana (Cuadro 3). A algunos de ellos, concretamente a tres, al parecer se les consideró como capellanías con el transcurrir del tiempo, aunque las fuentes manejadas no lo aclaran con precisión.

Los beneficios se conocen por el nombre de la familia que los fundó, por el de la capilla donde se ubican o por las tierras de donde proceden los fondos para su sustento. Los fundadores o patronos de estos beneficios suelen ser miembros de las familias más notables del obispado, como los Monterdes, Lagunillas, Toyuelas, Arganzas, Oruños, Rubios...; la mayoría de ellas ocupan ya una posición social relevante desde la Edad Media, la cual conservaron en los primeros siglos de la

17. Código de derecho canónico. Código de 1917. Versión castellana anotada por L. MiguéLez, S. Alonso y M. Cabreros, Madrid, BAC, 1978, título XXV, 1409-1488.

18. Sobre la definición y características de los beneficios, vid. Barrio Gozalo, M.: Iglesia y sociedad en Segovia: Siglos XVI-XIX. Valladolid, 2005, pp. 47-49. 
modernidad $^{19}$. Su presencia en las capillas de la catedral como fundadores les reportaba, además de beneficios espirituales, reconocimiento social y ponía de manifiesto su posición destacada en el seno de la comunidad. Una parte de esas familias tenían reconocido el derecho de enterramiento en sus respectivas capillas, en algunas de las cuales se recordaba a los benefactores con la presencia de sus escudos familiares incrustados en la correspondiente capilla ${ }^{20}$. La mayor parte, hasta 10 beneficios, los fundaron en el siglo Xvi, siete proceden ya de los siglos XIV y XV, mientras se desconoce la fecha de fundación en los cinco restantes. Son fundaciones anteriores al concilio de Trento y representan un tipo de religiosidad desarrollada antes del mismo, aunque de él saliera reforzada.

La renta media de los beneficios ascendía a 118 escudos (2.360 sueldos), cantidad estimable que permitiría vivir con desahogo a los titulares de los mismos ${ }^{21}$. Como es habitual en este tipo de instituciones, los clérigos que ocupan los beneficios suelen ser parientes de los fundadores, pues el beneficio, además de los frutos espirituales, sirve para garantizar el sustento de los descendientes del linaje fundador. Normalmente suele exigirse la ordenación sacerdotal para ocupar un beneficio, bien sea en el momento de tomar posesión o al cabo de un tiempo de la misma. No obstante, determinados beneficiados solo tienen alguna de las órdenes menores o mayores, pero no el presbiterado, razón por la cual no pueden oficiar las misas. Es el caso, en 1591, del beneficio de los Toyuelas, cuyas misas corren a cargo de los miembros del cabildo porque el beneficiado no es de misa, es decir, no reúne los requisitos canónicos para oficiarla. El beneficiado de los Arganzas, en la misma fecha, muestra al visitador del obispo su título de órdenes, pero no tiene la preceptiva colación canónica otorgada por el ordinario.

Los beneficiados están obligados a celebrar una serie de misas anuales que vienen especificadas en las fundaciones y que oscilan de unos beneficios a otros. Así, podemos ver cómo en cada uno de los beneficios dotados por el canónigo Ruesta se deben oficiar 26 misas anuales, mientras en el beneficio de los Garceses las misas dotadas ascienden a trescientas sesenta y cinco. Sin embargo, las dotaciones iniciales no siempre se cumplen, bien sea por disminución de las rentas consignadas a ese fin, negligencia de los beneficiados o descuido y abandono. Varios beneficios -Monterdes, Toyuelas, Torres, Arganzas, N. ${ }^{a}$ S. ${ }^{a}$ de los Ángeles y Morenos-, en

19. Sobre las principales familias del territorio en la Edad Media vid. Berges SÁnchez, J. M.: Actividad y estructuras pecuarias en la Comunidad de Albarracín (1284-1516). Tramacastilla (Teruel), 2009, pp. 398-469. Acerca de las familias que forman la elite política y social en la Edad Moderna vid. Cutanda Pérez, E.: La Comunidad de Albarracín en los siglos XVI y XVII (Hacienda, elites y poder). Tramacastilla (Teruel), 2010, pp. 215-353.

20. Tomás Laguía, C.: «Las capillas de la catedral de Albarracín», Teruel, 14, 1955, pp. 147-186.

21. Es una renta algo superior a la señalada por Domínguez OrTiz, A.: Las clases privilegiadas en la España del Antiguo Régimen. Madrid, 1973, p. 268. 


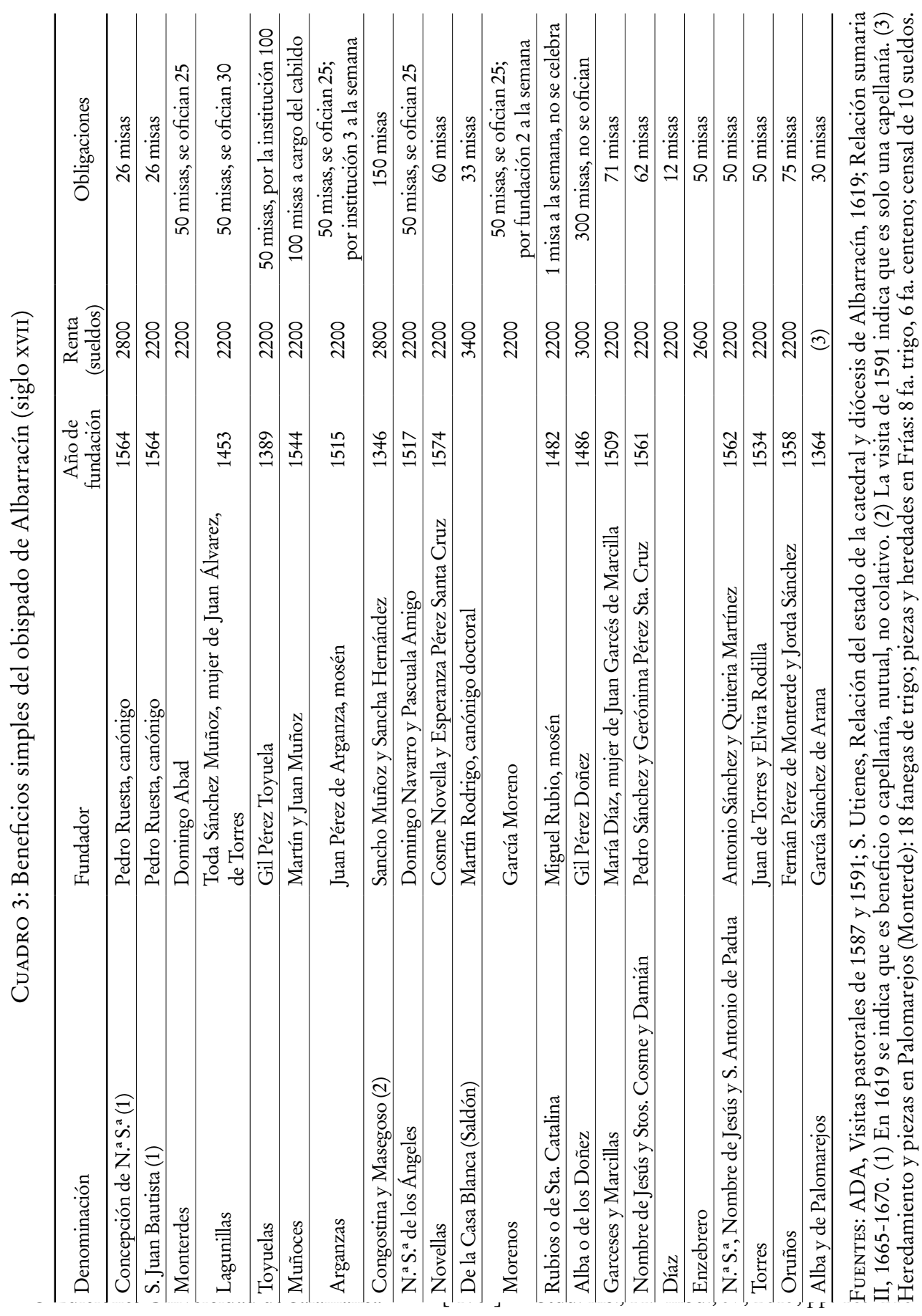


1619, celebran solo la mitad de las misas contempladas en la fundación. En el caso de los Garceses, la dotación inicial era una misa diaria, pero en 1619 celebran 71 al año. Dos beneficiados, de la casa Blanca y del Enzenebro, en la visita de 1591, declaran desconocer cuántas misas deben oficiar. En los beneficios de los Doñez y los Rubios, en 1619, simplemente no se oficia ninguna. El transcurrir del tiempo, por tanto, dificulta el cumplimiento de las voluntades de los fundadores que, por diversas circunstancias, acaban siendo conculcadas.

Todos estos beneficios tienen unos patronos, que son los encargados de gestionarlos, es decir de recaudar las rentas, vigilar el cumplimiento de las obligaciones y presentar a los candidatos a beneficiados. Normalmente ejercen el patronazgo parientes de los fundadores, bien en solitario, bien en compañía de terceros; a veces, en ausencia de parientes, se delega tal función en el cabildo, como es el caso de los Rubios o el de la casa Blanca. El patronazgo del beneficio del Alba y Palomarejos estuvo en disputa; en 1619 se afirma que es de patronato eclesiástico, aunque pretende ser patrona la familia Sánchez Muñoz.

\section{LAS CAPELLANÍAS}

Las capellanías son fundaciones, con vocación de perpetuidad, a las que se adjudica una serie de bienes para, con el fruto de los mismos, mantener un capellán que oficie un número determinado de misas, o realice otros actos de culto, en sufragio de las almas de los fundadores. Las llamadas colativas son, prácticamente, beneficios simples, con los que a menudo se confunden; son instituidas con intervención de la autoridad eclesiástica, el capellán es provisto mediante colación canónica y sus bienes son considerados eclesiásticos. Las laicales, por el contrario, son instituidas por los laicos y los bienes no pasan a la Iglesia, la cual, no obstante, vela para que se cumplan las disposiciones espirituales ${ }^{22}$.

Las razones para fundar capellanías eran de diversa índole y en ellas se mezcla, de manera natural y difícilmente separable, la intencionalidad religiosa con otras más mundanas ${ }^{23}$. Se busca, sin duda, realizar una buena obra y obtener sufragios

22. González Ruiz, op. cit., pp. 477-479. Barrio Gozalo, op. cit., p. 114. Pro Ruiz, J.: «Las capellanías: familia, iglesia y propiedad en el Antiguo Régimen», Hispania Sacra, 41, 1989, pp. 585-586. Catalán Martínez, E.: El precio del..., op. cit., pp. 163-165.

23. Sobre las razones que impulsan a fundar capellanías, vid. Von Wobeser, G.: «La función social y económica de las capellanías de misas en la Nueva España del siglo XviII», Estudios de Historia Novohispana, 16, 1996, pp. 123-135; Catalán Martínez, E.: «El derecho de patronato y el régimen beneficial de la iglesia española en la Edad Moderna», Hispania Sacra, 56, 2004, p. 166; Herreros Moya, G. J.: «Así en la tierra como en el cielo. Aproximación al estudio de las capellanías en la Edad Moderna: entre la trascendencia y la política familiar. El caso de Córdoba», Historia y Genealogía, 2, 2012, pp. 118-123; Pro Ruiz, op. cit., pp. 588-591; Castro Pérez, C.; Calvo Cruz, M. y Granado Suárez, S.: «Las capellanías en los siglos XVII-XVIII a través del estudio de su escritura de fundación», Anuario de 
por el alma para salvarla de la condenación o de una larga estancia en el lugar de purgación. Algunos fundadores expresan claramente la obligación de rezar por las almas del purgatorio y la importancia salvadora del sacrificio de la misa ${ }^{24}$.

La finalidad religiosa de las capellanías se completó con otros usos que atienden a las necesidades económicas y sociales de las familias. Estas utilizaron también las capellanías como una forma de asegurar la manutención de sus descendientes, que eran los llamados a ejercer de capellanes en sus fundaciones. La capellanía actuaba como fórmula para vincular una parte del patrimonio a uno de los hijos, que ejercería de capellán y se beneficiaría de las rentas anexas a la misma. Era una forma de atender a los descendientes excluidos del mayorazgo, dentro de las familias nobles. El componente familiar, el cuidado del linaje, de la parentela, que se refleja en la fundación de capellanías, ha sido destacado por la historiografía. Los fundadores encargan misas para sí y para sus allegados, nombran patronos de la institución a los parientes y reservan el puesto de capellán para sus deudos. Esta amalgama de espiritualidad y de cuidado de la familia convierte a la capellanía en una institución muy útil para amplias capas de la sociedad.

Las capellanías, por otra parte, tienen un componente de prestigio social, de reconocimiento de la persona y del linaje en el marco de una sociedad que otorga un gran valor a la posición ocupada en la jerarquía social. La fundación de las mismas supone una demostración pública de una cierta capacidad económica y de la piedad y desprendimiento del fundador, lo que añade honor y contribuye a dibujar la imagen social de las familias. Además, la capellanía, nacida con vocación de perpetuidad, asegura la pervivencia del recuerdo terrenal de personas y familias más allá de la muerte.

Una parte de las capellanías, las llamadas de almas, surgen por iniciativa de los concejos y párrocos locales. Se nutren económicamente de las pequeñas donaciones de particulares que carecen de los medios para fundar por sí mismos y de las limosnas que se recaudan. Dado que en la diócesis no existen apenas cofradías de

Historia de la Iglesia, 16, 2007, p. 337; Acosta Barros, L. M.: «Las capellanías en la isla de El Hierro durante el Antiguo Régimen», Anuario de Estudios Atlánticos, 38, 1992, p. 177; Soria MesA, E.: «Las capellanías en la Castilla moderna: familia y ascenso social», en IrigoYen López, A. y PÉrez OrTIZ, A. L. (eds.): Familia, transmisión y perpetuación (siglos XVI-XIX). Murcia, 2002, pp. 138-147.

24. "Considerando que los fieles christianos que estamos en la presente vida tenemos obligación de rogar por las ánimas del purgatorio y en especial por las ánimas de nuestros difuntos, porque Dios nuestro señor les perdone sus pecados, y a la mía, toda y hora y cuando Dios nuestro señor tuviere por bien de llevalla de esta presente vida en la otra, por cuanto no hay en este mundo otro beneficio ni cosa mayor ni de que dichas ánimas puedan recibir mayor beneficio y sufragio como es el del santo sacrificio de la misa»; Capellanía de Quiteria Baratagui, de Moscardón, ADA, Libro de la institución de capellanías del obispado de Albarracín hasta el año 1788, fol. 446. El clérigo José Benito Bayardo, fundador de la capellanía de S. Bernardo, de Gea de Albarracín, expresa que la funda a honra y gloria del Señor y de su Madre, por sufragio de su alma y de sus parientes y amigos; Archivo Municipal de Albarracín [en adelante AMA], Sección II-3, Dc. 27. 
almas, estas capellanías colectivas cumplen la función de llevar alivio espiritual al común de las gentes, organizando la obtención de sufragios por las almas de forma colectiva o socializada. La finalidad exclusivamente espiritual, orientada a la salvación de las almas, queda bien patente en estas capellanías.

En el obispado de Albarracín se detectan, a lo largo del siglo XviI, hasta 215 capellanías (Cuadro 4), lo que supone una media de casi ocho por localidad y de una capellanía por cada 52 habitantes ${ }^{25}$, datos que por sí solos hablan de la extensión de esta fórmula en la economía de la salvación ${ }^{26}$.

Cuadro 4: Número de capellanías en el obispado de Albarracín (siglo Xvir)

\begin{tabular}{lccc}
\hline Localidad & Número & Localidad & Número \\
\hline Albarracín & 11 & Noguera & 8 \\
Alobras & 3 & Orihuela & 15 \\
Bronchales & 11 & Pozondón & 8 \\
Calomarde & 6 & Ródenas & 10 \\
El Cuervo & 2 & Royuela & 4 \\
Frías & 12 & Saldón & 5 \\
Gea & 4 & Terriente & 17 \\
Griegos & 2 & Tormón & 1 \\
Guadalaviar & 5 & Torres & 4 \\
Huélamo & 4 & Tramacastiel & 3 \\
Jabaloyas & 17 & Tramacastilla & 9 \\
Monterde & 10 & Valdecuenca & 12 \\
Moscardón & 10 & Villar del Cobo & 14 \\
Motos & 8 & TOTAL & 215 \\
\hline
\end{tabular}

FuENTES: ADA, Visitas pastorales de 1587 y 1591; S. Utienes, Relación del estado de la catedral y diócesis de Albarracín, 1619; Relación sumaria II, 1665-1670; Libro de la institución de capellanías del obispado de Albarracín hasta el año 1788. Archivo Municipal de Gea de Albarracín [en adelante AMGA], Sección I-5, Dc. 46, Sec. II-3, Dc. 125. AMA, Sección II-3, Dc. 27. Polo, J. J.: «La visita pastoral del obispo Pedro Jaime a la diócesis de Albarracín (1598-1599)», Teruel, 77-78, 1987, pp. 237-260.

25. La población del obispado, en 1619 , era de 2.782 vecinos (11.128 habitantes), según los datos aportados por S. Utienes, Relación del estado de la catedral y diócesis de Albarracín, 1619. El censo de 1709 arroja unos datos similares: 10.636 habitantes; Archivo Histórico Nacional [en adelante AHN] Consejos, leg. 19.002 .

26. La abundancia de beneficios simples y capellanías ya fue observada por Domínguez OrTIZ, op. cit., pp. 263-264. En el País Vasco, el número de capellanías por parroquia era de 2,78: CATALÁN Martínez, E.: El precio del..., op. cit., pp. 167-173. 
La renta media de estas capellanías es modesta, elevándose a 781 sueldos $^{27}$; la mayoría, concretamente 119 , tienen unas rentas inferiores a 1.000 sueldos, 66 se sitúan entre 1.000 y 2.000 sueldos y solo 5 superan los 2.000 sueldos, desconociéndose la renta de 25 capellanías. La renta procede, fundamentalmente, de censales, que se habrán de colocar sobre concejos o propiedades seguras, no sobre particulares, por ricos que sean, según se indica en algunas fundaciones; se busca, por tanto, la máxima seguridad en el cobro de la renta como garantía de que así se celebrarán las misas de sufragio ${ }^{28}$. Las hay también que perciben ingresos de tierras o casas. A pesar del celo por invertir en sitios seguros, es frecuente encontrar capellanías que han perdido una parte de sus rentas iniciales o la totalidad de las mismas. Algunas, desaparecidas durante un tiempo, vuelven de nuevo a ser instituidas. También se da el caso de agregaciones de capellanías, bien porque sean de una misma familia o por la disminución de sus rentas. Por otra parte, hay capellanías cuya renta va creciendo con el tiempo, como ocurre en algunas de almas, por efecto de las donaciones y de la recepción de limosnas; es el caso, por ejemplo, de Frías, donde las rentas de la capellanía de las almas se elevan a 736 sueldos en 1591, mientras un siglo después alcanzan los 2.044 sueldos.

La dotación de capellanías, beneficios y simples celebraciones, por otra parte, supuso la inmovilización de importantes recursos económicos con fines espirituales por parte de las familias. La renta media de las capellanías nos indica que el capital medio -calculando un interés promedio del 5 por ciento-por capellanía se situaba en unos 15.600 sueldos, mientras que el capital total destinado a su fundación se aproximaría a los dos millones de sueldos, con cuya renta pudieron vivir como rentistas los capellanes de las mismas.

La fundación de capellanías se concentra en la segunda mitad del xvi y la primera del XvII, donde se fundaron 111, mientras en el período anterior a 1551 se instituyeron $17 \mathrm{y}$ en la segunda mitad del seiscientos nacieron 27; dos proceden de los siglos XIV y xv, respectivamente, desconociéndose la fecha de fundación en 60 casos. Aunque el fenómeno de fundaciones es anterior al concilio de Trento -28 se fundaron antes del mismo-, no cabe duda que la religiosidad emanada del mismo contribuyó decisivamente a popularizar las capellanías; cabe indicar

27. La mayoría de las del País Vasco tenían una renta inferior a 1.100 reales de vellón: Catalán MARTínez, E.: El precio del..., op. cit., pp. 167-173. Enrique Soria considera que el patrimonio medio de las capellanías no es tan exiguo: SorIa Mesa, op. cit., pp. 139-141.

28. Por ejemplo, en la capellanía de S. Pedro (Orihuela), se indica que los censos se carguen sobre concejos, o sobre buenas propiedades. Igualmente, en la fundada por Juan Cavero de Marcilla, en Jabaloyas, se indica que los censales luidos se carguen sobre concejos, preferentemente sobre Jabaloyas o la comunidad de aldeas: ADA, Relación sumaria II, 1665-1670, fol. 163; Libro de la institución de capellanías del obispado de Albarracín hasta el año 1788, fols. 368 y 707. 
que 110, la mayor parte de las que tienen fecha conocida, vieron la luz desde la finalización del concilio ${ }^{29}$.

Los clérigos adquieren cierto protagonismo fundando 39 , es decir el $18 \%$ de las mismas. Un grupo importante -62 capellanías (29\%)- son dotadas por personas que forman parte de la elite local, familias cuyos miembros ejercen actividades económicas de cierto nivel y que aparecen sistemáticamente ocupando los cargos principales del gobierno de la comunidad de aldeas ${ }^{30}$. Las mujeres están muy presentes como promotoras, protagonizando la fundación de 24 (11\%) en solitario, a las que cabe sumar las $44(20,5 \%)$ que fundan conjuntamente con sus maridos. Los concejos, por su parte, impulsarán las capellanías de almas, de las que encontramos 17 (7,9\%), las cuales se forman con las pequeñas donaciones de multitud de fieles con pocos recursos para destinar a la salvación de sus almas ${ }^{31}$. La condición social de los fundadores se desconoce en 114 casos (53\%), donde no se ha podido establecer relación con las familias de notables locales, lo que hace pensar que, al menos una parte de ellas, fueron fundadas por personas de escasa relevancia social y económica.

Las capellanías disponen de patronos encargados por los fundadores de velar por su mantenimiento y de elegir al capellán, de acuerdo con las cláusulas de la institución. El patronazgo es ejercido exclusivamente por parientes en 44 casos $(20,5 \%)$ y acompañados por las autoridades municipales o por el rector de la parroquia en otras 29 capellanías (13,5\%). Son abundantes -54 casos $(25 \%)-$ los patronazgos ejercidos conjuntamente por el párroco y las autoridades concejiles. Hay catorce capellanías donde no está aclarada la procedencia de los patronos, una donde se recurre a un noble sin relación aparente con el fundador y en 73 casos $(34 \%)$ se carece de información. Por tanto, en los casos conocidos, predominan los parientes, en solitario o con otros copatronos, pero cabe también destacar el importante papel que juegan las autoridades municipales y los rectores de las parroquias como patronos de capellanías ${ }^{32}$.

29. La cronología de las fundaciones coincide con la observada en otras partes de España, salvo en El Hierro, donde se retrasa algo; Acosta Barros, op. cit., p. 160; Catalán Martínez, E.: «Seculares...», op. cit., pp. 388-391; Soria Mesa, op. cit., p. 144.

30. Se han cruzado los datos de las capellanías con las noticias sobre los miembros de la elite local aportadas por CuTANDA PÉREz, op. cit.; se ha consultado también su tesis doctoral, que incluye una amplia nómina de personas que ocuparon cargos públicos.

31. En Santiago predominan los labradores (44,18\%), el bajo clero $(33,33 \%)$ y los hidalgos $(13,17 \%)$; FERNÁNDEZ CuBEIRo, E.: «Una práctica de la sociedad rural: Aproximación al estudio de las Capellanías de la Diócesis Compostelana en los siglos xvir y XviII», en EIRAs Roel, A. (coord.): La historia social de Galicia en sus fuentes de protocolos. Santiago de Compostela, 1981, pp. 205-215. Los fundadores de capellanías en El Hierro son mayoritariamente laicos (72,1\%); AcOSTA BARRos, op. cit., pp. 148 y ss.

32. Juan Monterde, tesorero de la seo de Zaragoza, fundador de una capellanía en Frías, dispone que sea de patronato laico, pero podrán ser patronos sus hijos y nietos aunque sean clérigos, 
A los patronos corresponde la provisión del capellán encargado de oficiar las misas, el cual, en las capellanías colativas, requiere de la colación canónica efectuada por el obispo; sin embargo estas son muy escasas en el obispado, contabilizándose solo 16 en las localidades de Albarracín, Alobras, El Cuervo, Jabaloyas, Noguera, Torres, Valdecuenca y Villar del Cobo. Las demás son provistas por los patronos sin más límites que los impuestos por los fundadores; de hecho, no es infrecuente encontrar disposiciones donde se veda expresamente la injerencia de la autoridad eclesiástica en su gobierno, aunque el fundador sea un clérigo ${ }^{33}$. Por otra parte, las capellanías del obispado no sirven, salvo alguna excepción, como título para obtener órdenes, para una posterior ordenación sacerdotal del capellán ${ }^{34}$.

La historiografía sobre las capellanías ha señalado que los capellanes suelen ser parientes de los fundadores, pero la información manejada, en nuestro caso, sobre la relación entre los capellanes y los fundadores es imprecisa y solo puede asegurarse en unos pocos casos ese parentesco ${ }^{35}$. Por otra parte, aun cuando se reserven para parientes, siempre queda abierta la puerta para que puedan servirlas otros en ausencia de aquellos ${ }^{36}$. Los pleitos para probar el parentesco requerido para lucrarse con una capellanía abundaron, prueba evidente del interés que despertaban como medio de vida. El modo de selección de los capellanes de patronato condujo, de manera inevitable, a una baja calidad religiosa de los mismos, situación que denuncia, entre otros, Juan de Ávila ${ }^{37}$.

siempre que no sean frailes ni teatinos: ADA, Libro de la institución de capellanías del obispado de Albarracín hasta el año 1788. En Córdoba los patronos son los primogénitos de las familias; Herreros Moya, op. cit., pp. 127-128.

33. Capellanía de S. Diego, fundada en Bronchales por mosén Diego Cañete, en 1624: ADA, S. Utienes, Relación del estado de la catedral y diócesis de Albarracín, 1619, fol. 86v.

34. El capellán de la capellanía fundada en Frías por Juan Monterde puede ser ordenado a título de ella: ADA, Libro de la institución de capellanías del obispado de Albarracín hasta el año 1788. Lo mismo ocurre en la capellanía de S. Bernardo, de Gea de Albarracín: AMA, Sección II-3, Dc. 27.

35. La capellanía es vista también como una salida familiar dentro de la planificación del futuro de los hijos, un instrumento para mantener a un deudo: Herreros Moya, op. cit., pp. 131-134.

36. La capellanía de los Iranzos (Jabaloyas) es para descendientes de los hermanos Cavero de Marcilla, pero si no hay candidatos del linaje será para hijos de Jabaloyas y, si no los hubiere, para hijos de la comunidad de Albarracín o, finalmente, para aragoneses. Es una capellanía que permite promocionar a las sagradas órdenes y tiene obligación de residencia; ADA, Libro de la institución de capellanías del obispado de Albarracín hasta el año 1788, fol. 368. En la capellanía fundada en Frías por Juan Monterde, el capellán ha de ser de la familia de los Monterdes y, si de ella no lo hay, de los Alonsos, y si tampoco lo hay de esta se elige a uno de Frías, en primer lugar, y, si de esta localidad no lo hubiere, se buscará uno del territorio de la comunidad. Cuando el capellán es de la familia, solo puede ser desposeído si se ausenta, vive amancebado o por beodez o locura; ADA, S. Utienes, Relación del estado de la catedral y diócesis de Albarracín, 1619, fol. 130v. y Libro de la institución de capellanías del obispado de Albarracín hasta el año 1788, fol. 249.

37. «Lo que en lo dicho se ha pretendido es que los que han de ser eclesiásticos, sean llamados y no enjeridos, y ninguno sea ordenado si no fuere criado en los dichos colegios, porque en esto parece consistir el remedio de ellos, y así conviene guardarse en todo caso. Para esto parece que puede haber 
La principal obligación de los capellanes era oficiar las misas encargadas por los fundadores, existiendo una gran variedad en cuanto a su número, que obviamente dependía de la dotación económica. La media de misas por capellanía se sitúa en 159 anuales, por encima de lo observado en otros lugares ${ }^{38}$. Es relativamente frecuente encontrar capellanías donde las celebraciones iniciales han disminuido o desaparecido, por efecto de la pérdida de rentas o por la mala administración. En otros casos, por el contrario, se hallan capellanías a las que se han agregado misas con posterioridad a su fecha de fundación.

Los clérigos suelen tener la obligación de residir en el pueblo donde está fundada la capellanía, a la que han de servir en exclusiva ${ }^{39}$. Las ausencias permitidas no suelen ir más allá de dos meses al año, pero manteniendo la obligación de celebrar las misas durante la ausencia.

Algunos capellanes, si el párroco de la localidad los admite, pueden participar en las ceremonias del culto parroquial, percibiendo por ello la correspondiente distribución. Otros tienen encomendadas tareas añadidas a la principal de oficiar las misas. El capellán de la sacristía de Tramacastiel ha de cantar en el coro, preparar el altar para el culto, cuidar la sacristía y enseñar la doctrina los días de fiesta. El capellán de la capellanía de almas de Guadalaviar, por su parte, podrá optar a ocupar el cargo de sacristán con la obligación de enseñar a leer a los niños y la doctrina cristiana. Tendrá la condición de confesor aprobado por el ordinario y se le asigna la obligación de asistir a los divinos oficios, conjurar, asistir a las rogativas y procesiones de Minerva, del Jesús y del Rosario, que se hacen cada mes. Por su parte, el capellán de la de almas de Alobras tiene anexa la sacristía y debe asistir al coro y a las funciones de la iglesia; enseña a leer, escribir y la doctrina a los niños,

inconveniente por los patronazgos que algunas personas tienen de presentar a beneficios o capellanías. Porque como los tales tengan esto por granjería y no tengan sus ojos puestos en elegir al más digno, sino el padre presenta al hijo o al pariente, y el señor a su criado; y como estos presentados acaece ni ser inclinados, ni haber gana, ni tener la disposición que es menester para ser de la Iglesia, y sólo [son] incitados a serlo por el mando o interese ajeno o proprio, salen malos clérigos y turban la orden dada»: Ávila, J. de: Obras completas del Santo Maestro Juan de Ávila. Madrid, 1971, Tomo VI, p. 55.

38. Para calcular la media se tiene en cuenta solo las capellanías de las que se tiene información sobre el número de misas que celebran, que son 184. En El Hierro la media de misas por capellanía no llega a 75: Acosta Barros, op. cit., p. 164.

39. La obligación de residir en el lugar donde se halla fundada la capellanía se aprecia, por ejemplo, en las siguientes: Juan Monterde (Frías), N. ${ }^{a}$ S. ${ }^{a}$ del Carmen (Griegos), S. Fabián y S. Sebastián (Orihuela), almas (Orihuela), Pedro Catalán (Pozondón), S. Juan Bautista (Monterde), Sacristía (Tramacastiel) o la de los clérigos Antonio y Pedro Fuertes (Tramacastilla); ADA, S. Utienes, Relación del estado de la catedral y diócesis de Albarracín, 1619, fols. 38-42v, 45v-50, 91v-92, 178v; Relación sumaria II, 1665-1670, fols. 154, 170, 176, 469-471 y Libro de la institución de capellanías del obispado de Albarracín hasta el año 1788. La obligación de residencia también se observa en El Hierro: Acosta Barros, op. cit., pp. 193-195. 
los cuales pagan mensualmente un sueldo por enseñarles a leer y tres si se trata de aprender a leer y escribir ${ }^{40}$.

Los capellanes suelen ser presbíteros, aunque se puede dar la circunstancia de que alguno no lo sea, en cuyo caso habrá de mandar celebrar las misas correspondientes a otra persona con capacidad para ello.

\section{Celebraciones}

La mayor parte de las familias no disponían de los recursos suficientes para fundar una capellanía, pero sí les alcanzaba para donar una cantidad de dinero a la iglesia de su localidad con el fin de fundar una celebración o memoria de misas en sufragio de sus almas. El dinero, o las propiedades donadas, en este caso, eran administradas por el cura de la parroquia, que oficiaba las correspondientes misas, mientras las rentas donadas no sufrieran merma ${ }^{41}$.

Seguir el rastro de las celebraciones es más complicado porque no suelen dejar tanta huella documental como los beneficios o las capellanías; en ocasiones, resulta difícil distinguir entre una capellanía o una celebración de cierta importancia debido a las propias dudas que arroja la documentación ${ }^{42}$. Sin duda existieron celebraciones en todas las parroquias, pero solo se han hallado datos de trece (Cuadro 5).

La renta media de las celebraciones se sitúa en 269 sueldos, cuando la de las capellanías se elevaba a 781. Esto se traduce en un menor número de misas, situándose el promedio en 70 por celebración, en tanto que en las capellanías se eleva a 159 , en los casos donde este dato se conoce. Son, por tanto, fundaciones menores, pero que sirven al mismo fin principal: tratar de asegurar la salvación del alma y abreviar su estancia en el purgatorio.

40. ADA, S. Utienes, Relación del estado de la catedral y diócesis de Albarracín, 1619, fols. 123-123v, 170v-172 y 178v. y Libro de la institución de capellanías del obispado de Albarracín hasta el año 1788 , fols. 39 y 330 .

41. Sobre las memorias de misas vid. Catalán Martínez, E.: El precio del..., op. cit., p. 175 y «El derecho de...», op. cit., p. 157; González Ruiz, op. cit., pp. 483-484; Ruiz PÉrez, A.: «Las capellanías, los Patronatos y las Memorias de misas en El Coronil en los siglos xvi y xviı», en GARcía FERnÁndez, M. (coord.): I Jornadas de Historia y Patrimonio de la Provincia de Sevilla: una revisión bistoriográfica. Sevilla, 2007, pp. 211-214. Soriano Triguero, C.: «Actitudes económico-espirituales de las clarisas madrileñas: la administración de memorias y capellanías en el convento de Ntra. Sra. de los Ángeles en el siglo xviII», en Martínez Ruiz, E. y SuÁrez Grimón, V. (eds.): Iglesia y Sociedad en el Antiguo Régimen. Las Palmas, 1994, vol. I, p. 377.

42. Así ocurre con la llamada celebración de Domingo Toribio, en Bronchales; en el propio documento de fundación se habla indistintamente de celebración y de capellanía: ADA, Relación sumaria II, 1665-1670, fol. 195; Libro de la institución de capellanías del obispado de Albarracín hasta el año 1788 , fol. 86 . 
JOSÉ MANUEL LATORRE CIRIA

LAS OBRAS PÍAS COMO CAMINO DE SALVACIÓN: EL OBISPADO DE ALBARRACÍN (SIGLO XVII)

CuAdro 5: Número de celebraciones en el obispado de Albarracín (siglo xviI)

\begin{tabular}{lccc}
\hline Localidad & Número & Localidad & Número \\
\hline Albarracín & & Noguera & Orihuela \\
Alobras & 3 & Pozondón & 3 \\
Bronchales & Ródenas & 1 \\
Calomarde & Royuela & 2 \\
Cuervo, El & 8 & Saldón & \\
Frías & & Terriente & 9 \\
Gea & & Tormón & 5 \\
Griegos & 3 & Torres & \\
Guadalaviar & 2 & Tramacastiel & 2 \\
Huélamo & 5 & Tramacastilla & \\
Jabaloyas & 3 & Valdecuenca & 3 \\
Monterde & Villar del Cobo & \\
Moscardón & & TOTAL & 58 \\
Motos & & Utione
\end{tabular}

Fuentes: ADA, Visitas pastorales de 1587 y 1591; S. Utienes, Relación del estado de la catedral y diócesis de Albarracín, 1619; Relación sumaria II, 1665-1670.

Las celebraciones fueron fundadas por mujeres (14 casos), clérigos (7), matrimonios (6), cofradías (4) y diversas personas sin datos sobre ellas; en general, puede decirse que se trata de personas sin protagonismo social dentro de sus comunidades.

El panorama que ofrecen las obras pías muestra cómo la celebración de misas, la adoración a Dios mediante el sacrificio de la misa, tiene un papel central en la vivencia de la religión y en la búsqueda de la salvación eterna. No había pueblo, cualquiera que fuese su tamaño, donde no se celebrasen varias misas diarias en sufragio por los muertos.

En el cuadro 6 se han recogido las misas fundadas en cada pueblo pertenecientes a beneficios, capellanías, celebraciones, aniversarios y doblas ${ }^{43}$ a fines del siglo xvir. Se trata de una cifra aproximada y, en todo caso, mínima, pues en los casos de las celebraciones, aniversarios y doblas es seguro que no se han podido documentar todas las existentes. Por otra parte, en las misas de fundación, suele ocurrir que, con el paso del tiempo, una parte de las misas inicialmente dotadas

43. Las doblas aparecen junto a los aniversarios y entiendo que se trata de una celebración similar al aniversario pero con oficio doble, es decir incorporando algún oficio complementario, como vísperas o maitines. 
JOSÉ MANUEL LATORRE CIRIA

LAS OBRAS PÍAS COMO CAMINO DE SALVACIÓN: EL OBISPADO DE ALBARRACÍN (SIGLO XVII)

CuAdro 6: Número de misas en el obispado de Albarracín (finales del xviI)

\begin{tabular}{|c|c|c|c|c|c|c|}
\hline Localidades & Beneficios & Capellanías & Celebraciones & $\begin{array}{c}\text { Aniversarios y } \\
\text { doblas }\end{array}$ & Total & Media diaria \\
\hline Albarracín & 975 & 1222 & & & 1977 & 5,42 \\
\hline Alobras & & 408 & & 213 & 408 & 1,12 \\
\hline Bezas & & & & 10 & & \\
\hline Bronchales & & 1434 & 394 & 104 & 1828 & 5,01 \\
\hline Calomarde & & 1151 & & & 1151 & 3,15 \\
\hline Cuervo, El & & 620 & & 143 & 620 & 1,70 \\
\hline Frías & & 1404 & 650 & 129 & 2054 & 5,63 \\
\hline Gea & & 177 & & 128 & 177 & 0,48 \\
\hline Griegos & & 424 & & & 424 & 1,16 \\
\hline Guadalaviar & & 447 & 414 & 116 & 861 & 2,36 \\
\hline Huélamo & & 480 & 18 & & 498 & 1,36 \\
\hline Jabaloyas & & 1942 & 204 & 453 & 1938 & 5,31 \\
\hline Monterde & & 1325 & 203 & & 1528 & 4,19 \\
\hline Moscardón & & 1416 & & 115 & 1416 & 3,88 \\
\hline Motos & & 1475 & & & 1475 & 4,04 \\
\hline Noguera & & 906 & 175 & & 1081 & 2,96 \\
\hline Orihuela & & 2780 & & 226 & 2780 & 7,62 \\
\hline Pozondón & & 1102 & 222 & 623 & 1346 & 3,69 \\
\hline Ródenas & & 1376 & & 336 & 1376 & 3,77 \\
\hline Royuela & & 421 & 269 & 104 & 690 & 1,89 \\
\hline Saldón & & 719 & & 181 & 719 & 1,97 \\
\hline Terriente & & 2562 & 294 & 367 & 2856 & 7,82 \\
\hline \multicolumn{7}{|l|}{ Tormón } \\
\hline Torres & & 724 & 42 & 82 & 766 & 2,10 \\
\hline Tramacastiel & & 401 & & 300 & 401 & 1,10 \\
\hline Tramacastilla & & 1146 & 193 & & 1339 & 3,67 \\
\hline Valdecuenca & & 567 & 116 & & 683 & 1,87 \\
\hline Villar del Cobo & & 2840 & & 177 & 2840 & 7,78 \\
\hline TOTAL & 975 & 29261 & 3216 & 3807 & 37259 & 102,07 \\
\hline
\end{tabular}

FuENTES: ADA, Visitas pastorales de 1587 y 1591; S. Utienes, Relación del estado de la catedral y diócesis de Albarracín, 1619; Relación sumaria II, 1665-1670; Libro de la institución de capellanías del obispado de Albarracín hasta el año 1788.

(C) Ediciones Universidad de Salamanca

[205] Stud. his., H. ${ }^{a}$ mod., 37, 2015, pp. 183-210 
JOSÉ MANUEL LATORRE CIRIA

LAS OBRAS PÍAS COMO CAMINO DE SALVACIÓN: EL OBISPADO DE ALBARRACÍN (SIGLO XVII)

Cuadro 7: Número de habitantes y de clérigos en el obispado de Albarracín (1709)

\begin{tabular}{|c|c|c|c|}
\hline Localidades & $\begin{array}{l}1709 \\
\text { Total habitantes* }\end{array}$ & $\begin{array}{c}1709 \\
\text { Clérigos } \\
\end{array}$ & $\begin{array}{c}1709 \\
\text { Habitantes/clérigo }\end{array}$ \\
\hline Albarracín & 1166 & 46 & 25,35 \\
\hline Alobras & 255 & 3 & 85,00 \\
\hline Bezas & 125 & 1 & 125,00 \\
\hline Bronchales & 499 & 11 & 45,36 \\
\hline Calomarde & 317 & 5 & 63,40 \\
\hline Cuervo, El & 240 & 4 & 60,00 \\
\hline Frías & 603 & 7 & 86,14 \\
\hline Gea & 588 & 4 & 147,00 \\
\hline Griegos & 222 & 2 & 111,00 \\
\hline Guadalaviar & 397 & 5 & 79,40 \\
\hline Huélamo & 323 & 3 & 107,67 \\
\hline Jabaloyas & 719 & 11 & 65,36 \\
\hline Monterde & 355 & 11 & 32,27 \\
\hline Moscardón & 394 & 6 & 65,67 \\
\hline Motos & 122 & 2 & 61,00 \\
\hline Noguera & 310 & 6 & 51,67 \\
\hline Orihuela & 506 & 10 & 50,60 \\
\hline Pozondón & 264 & 8 & 33,00 \\
\hline Ródenas & 159 & 3 & 53,00 \\
\hline Royuela & 168 & 4 & 42,00 \\
\hline Saldón & 309 & 5 & 61,80 \\
\hline Terriente & 985 & 17 & 57,94 \\
\hline Tormón & 121 & 1 & 121,00 \\
\hline Torres & 291 & 3 & 97,00 \\
\hline Tramacastiel & 224 & 4 & 56,00 \\
\hline Tramacastilla & 241 & 5 & 48,20 \\
\hline Valdecuenca & 241 & 5 & 48,20 \\
\hline Villar del Cobo & 492 & 8 & 61,50 \\
\hline TOTAL & 10636 & 200 & 53,18 \\
\hline
\end{tabular}

Fuentes: AHN, Consejos, Leg. 19.002; *Incluye los clérigos.

(C) Ediciones Universidad de Salamanca

[ 206 ] Stud. his., H. ${ }^{a}$ mod., 37, 2015, pp. 183-210 
acaban por no celebrarse debido a la pérdida de rentas, a la mala administración o a cualquier otra circunstancia ${ }^{44}$. Las únicas capellanías que suelen aumentar su volumen de misas son las de almas, dado que se benefician de la acumulación de pequeños legados y limosnas para la celebración de misas de forma continua. Son más de 37.000 las misas anuales, que suponen un promedio diario de 102 en el conjunto del pequeño obispado y de cerca de 4 por localidad. El obispado era pequeño y contaba, a comienzos del siglo xviıI, con 10.636 habitantes ${ }^{45}$. Según estos datos, la media de misas por persona y año se situaría en 3,5.

La salvación a través de las misas requería de un amplio colectivo de clérigos dedicados exclusivamente a oficiar las misas de fundación. El obispado contaba, en 1709, con 200 clérigos (Cuadro 7), de los cuales casi la cuarta parte residían en Albarracín, cabecera de la diócesis, como suele ser habitual en la España moderna, donde la mayor densidad de clérigos se da en las ciudades. Estas cifras de clérigos suponen que, de media, hay más de siete por localidad y un clérigo por cada 53 habitantes. Sin embargo, los clérigos dedicados a la cura de almas eran los titulares de las parroquias, que ascendían a 29 en el conjunto del obispado de Albarracín. Las cuatro dignidades, los ocho canónigos y los beneficiados de la catedral, en torno a treinta, estaban dedicados al culto en el primer templo de la diócesis. Por tanto, a comienzos del setecientos, estaríamos hablando de la existencia de unos 130 capellanes que se mantenían con los réditos de las fundaciones de los fieles en sufragio por sus almas.

\section{Conclusiones}

La salvación del alma era un objetivo importante en la vida para la mayoría de las personas y la Iglesia procuró ofrecer los medios adecuados para conseguirla. Las buenas obras, las obras pías, se constituyeron en un canal adecuado para esa finalidad.

Una parte de las mismas se dirige a la atención a los pobres, sujetos de la caridad de los fieles porque ese era un acto que se entendía como bueno a los ojos de Dios. Al fin y al cabo, el deber de ejercer la caridad con el necesitado está en las entrañas del Evangelio. La mayor parte de las limosnas tienen como finalidad atender a pobres y dotar a muchachas en el momento de contraer matrimonio. Una buena parte de esas limosnas, cerca del cincuenta por ciento, se destinan preferentemente a parientes, cumpliendo así la doble finalidad de favorecer al alma del donante y a

44. Según Soriano, son muy escasas las fundaciones en las que se conserva, con el tiempo, el número original de misas fundadas: Soriano Triguero, op. cit., p. 379.

45. Censo de población de 1709 en AHN, Consejos, leg. 19.002. 
los familiares del mismo. Los clérigos se acordarán de la familia en mayor medida que los seglares y también fundarán limosnas mejor dotadas económicamente.

Sin embargo, la fórmula más extendida es la fundación de misas bajo distintas modalidades: beneficios, capellanías, aniversarios, memorias de misas... Se trata de rendir culto a Dios, tal vez más que de vivir sus exigencias morales, por medio del sacrificio de la misa, obteniendo así los beneficios espirituales necesarios para eludir o abreviar la estancia en el purgatorio. Las ceremonias de culto externo -misas, rezo de horas canónicas, procesiones, etc.- cobran una importancia fundamental como praxis del cristiano, como instrumentos de salvación. La solidaridad con los familiares difuntos se muestra en el rezo por ellos, de la misma forma que se espera de los descendientes un recuerdo por los que les precedieron.

La fundación de beneficios simples corresponde a personas vinculadas con las familias de notables locales, que hunden sus raíces en la Edad Media. Fundan beneficios en las capillas de la catedral con el fin de obtener gracias espirituales, pero también para dejar perpetua memoria de sus nombres y mostrar su posición social dominante. Adquieren el derecho de sepultura en las capillas y, en ocasiones, dejan sus escudos heráldicos labrados en las paredes de las mismas, para dejar clara la propiedad del linaje y el espíritu benefactor de la familia.

Los beneficios suelen estar dotados con rentas estimables que disfrutan, con frecuencia, beneficiados que son miembros de la familia y a los que se les suministra un medio de vida con la obligación de rezar por sus antepasados difuntos. El transcurrir del tiempo, no obstante, suele difuminar las fundaciones y el cumplimiento de sus estipulaciones; las rentas caen, y con ellas las misas, a la par que los beneficiados pueden no ser familiares.

Más abundantes son las capellanías, en cuya fundación se entremezclan razones de diversa índole. Se busca, sin duda, realizar una buena obra a favor del alma. Claramente queda expresada en determinadas fundaciones la importancia salvadora del sacrificio de la misa, su importancia como medio de salvación. A la finalidad religiosa se suma el interés de las familias por vincular una parte de su patrimonio para sustento de algún descendiente clérigo, que se beneficia de la renta de la capellanía. Tienen también un componente de prestigio social, contribuyen a dibujar la imagen social de las familias que las fundan y a perpetuar su memoria. Esto sería así en cerca del treinta por ciento de las capellanías, fundadas por miembros de la elite local.

No obstante, una parte de las capellanías, las llamadas de almas, existentes en todos los pueblos, que surgen por iniciativa de los concejos y párrocos locales, tienen una finalidad exclusivamente religiosa. Aquí no hay elementos que difuminen el componente religioso de estas fundaciones. Por otra parte, la mayor parte fueron fundadas por personas de escasa relevancia social, en cuyo caso el factor religioso también parece predominar. 
La mayor parte de las familias no disponían de recursos para instituir beneficios o capellanías, por ello se limitaban a fundar una celebración o memoria de misas en sufragio de sus almas.

La fundación de capellanías y beneficios responde a la búsqueda de gracias espirituales, pero estos instrumentos ofertados por la Iglesia a los fieles como camino de salvación ofrecían evidentes ventajas sociales. A través de estas fórmulas se podía asegurar el futuro de un pariente, se perpetuaba la memoria y el nombre del fundador y la vanidad de los linajes quedaba satisfecha. Al morir, las personas se desprendían de una parte de su patrimonio, entregado al clero, para que rezara por su alma, pero los instrumentos empleados, sobre todo las capellanías, permitían que esa porción de los bienes acumulados a lo largo de la vida, al menos en bastantes casos, no saliera fuera del entorno familiar. Las obras pías se convierten así en instrumento de salvación, pero también de solidaridad y apoyo a la familia. Por otra parte, el clero, los hombres de Iglesia, no dejaban así de crecer contribuyendo al engrandecimiento de la misma. Son, pues, instrumentos de salvación perfectamente diseñados para dar satisfacción a todas las partes implicadas, para obtener satisfacción espiritual sin dejar de atender a la familia, al honor y prestigio de la misma. Incluso en la fundación de limosnas, acto caritativo por excelencia, el interés por beneficiar a la familia es evidente, situando a los pobres del linaje, o a las doncellas casaderas del mismo, en el primer lugar de las preferencias a la hora de percibir las ayudas contempladas en las limosnas fundadas.

\section{BibLIOgRAFÍA}

Acosta Barros, L. M.: «Las capellanías en la isla de El Hierro durante el Antiguo Régimen», Anuario de Estudios Atlánticos, 38, (1992), pp. 141-198.

Ardanaz, N.: La catedral de Pamplona en el siglo de las luces. Arte, ceremonial y cultura. Pamplona, Universidad de Navarra, 2011, 939 pp.

Ávila, J. de: Obras completas del Santo Maestro Juan de Ávila. Madrid, BAC, tomo VI, 1971. Barrio Gozalo, M.: Iglesia y sociedad en Segovia: Siglos XVI-XIX. Valladolid, 2005.

Berges SÁnchez, J. M.: Actividad y estructuras pecuarias en la Comunidad de Albarracín (1284-1516). Tramacastilla (Teruel), 2009.

Castro Pérez, C.; Calvo Cruz, M. y Granado Suárez, S.: «Las capellanías en los siglos XVII-XviII a través del estudio de su escritura de fundación», Anuario de Historia de la Iglesia, 16, (2007), pp. 335-347.

Catalán Martínez, E.: «Seculares aragoneses después de Trento. La visita pastoral de D. Antonio Chacón a los valles del Jalón y Jiloca», Jerónimo Zurita, 76-77, (2004), pp. 369-397.

Catalán Martínez, E.: «El derecho de patronato y el régimen beneficial de la iglesia ESPAÑola en la Edad Moderna», Hispania Sacra, 113, (2004), pp. 135-168. 
JOSÉ MANUEL LATORRE CIRIA

LAS OBRAS PÍAS COMO CAMINO DE SALVACIÓN: EL OBISPADO DE ALBARRACÍN (SIGLO XVII)

Catalán Martínez, E.: El precio del Purgatorio. Los ingresos del clero vasco en la Edad Moderna. Bilbao, 2000.

CutAnda Pérez, E.: La Comunidad de Albarracín en los siglos XVI y XVII (Hacienda, elites $y$ poder). Tramacastilla (Teruel), 2010.

Domínguez Ortiz, A.: Las clases privilegiadas en la España del Antiguo Régimen. Madrid, 1973, 464 pp.

Fernández Cubeiro, E.: «Una práctica de la sociedad rural: Aproximación al estudio de las Capellanías de la Diócesis Compostelana en los siglos XviI y XviII», en EIRAS Roel, A. (coord.): La historia social de Galicia en sus fuentes de protocolos. Santiago de Compostela, 1981, pp. 205-215.

García Hinojosa, P.: Simbolismo, religiosidad y ritual barroco. La muerte en el siglo XVII. Zaragoza, 2013, 577 pp.

González Ruiz, M.: «Las capellanías españolas en su perspectiva histórica», Revista Española de Derecho Canónico, 14, (1950), pp. 482-485.

Herreros Moya, G. J.: «Así en la tierra como en el cielo. Aproximación al estudio de las capellanías en la Edad Moderna: entre la trascendencia y la política familiar. El caso de Córdoba», Historia y Genealogía, 2, (2012), pp. 118-123.

Le Goff, J.: El nacimiento del Purgatorio. Madrid, 1985.

López-Guadalupe Muñoz, J. J.: «Imágenes del más allá. Culto e iconografía de las ánimas en la Granada moderna», en CorTÉs PeÑA, A. L. (ed.): Poder civil, Iglesia y sociedad en la Edad Moderna. Granada, 2006, pp. 161-196.

Polo, J. J.: «La visita pastoral del obispo Pedro Jaime a la diócesis de Albarracín (15981599)», Teruel, 77-78, (1987), pp. 237-260.

Pro Ruiz, J.: «Las capellanías: familia, iglesia y propiedad en el Antiguo Régimen», Hispania Sacra, 41, 1989, pp. 585-586.

Prosperi, A.: El concilio de Trento. Una introducción histórica. Ávila, 2008, 168 pp.

Ruiz Pérez, A.: «Las capellanías, los Patronatos y las Memorias de misas en El Coronil en los siglos XVI y XVII», en García Fernández, M. (coord.): I Jornadas de Historia y Patrimonio de la Provincia de Sevilla: una revisión historiográfica. Sevilla, 2007, pp. 200-218.

Soria Mesa, E.: «Las capellanías en la Castilla moderna: familia y ascenso social», en Irigoyen López, A. y Pérez Ortiz, A. L. (eds.): Familia, transmisión y perpetuación (siglos XVI-XIX). Murcia, Universidad de Murcia, 2002, pp. 138-147.

Soriano Triguero, C.: «Actitudes económico-espirituales de las clarisas madrileñas: la administración de memorias y capellanías en el convento de Ntra. Sra. de los Ángeles en el siglo xvini», en Martínez Ruiz, E. y Suárez Grimón, V. (eds.): Iglesia y Sociedad en el Antiguo Régimen. Las Palmas, Universidad de Las Palmas de Gran Canaria, 1994, vol. I, pp. 375-383.

Tomás Laguía, C.: «Las capillas de la catedral de Albarracín», Teruel, 14, (1955), pp. 147-186.

Von Wobeser, G.: «La función social y económica de las capellanías de misas en la Nueva España del siglo xviII», Estudios de Historia Novohispana, 16, (1996), pp. 123-135. 